Юлія Твердохлєбова

Національний університет «Чернігівський колегіум» імені Т.Г. Шевченка ORCID ID 0000-0003-0752-052X

Андрій Красілов

Сумський державний педагогічний університет імені А. С. Макаренка ORCID ID 0000-0002-7725-5074

Михайло Лянной

Сумський державний педагогічний університет імені А. С. Макаренка ORCID ID 0000-0002-7128-072X

DOI 10.24139/2312-5993/2020.10/259-269

\title{
КОМПОНЕНТИ ГОТОВНОСТІ МАЙБУТНІХ ФАХІВЦІВ ФІЗИЧНОЇ КУЛЬТУРИ І СПОРТУ ВИКОРИСТОВУВАТИ ТЕХНОЛОГІЇ ВІДНОВЛЕННЯ ЗДОРОВ'Я У ПРОФЕСІЙНІЙ ДІЯЛЬНОСТІ
}

Нове українське суспільство потребує фрахівців фрізичної культури і спорту інноваційного типу, які поєднують здатність до творчої співпраці, володіють сучасними інновачійними технологіями відновлення здоров'я, володіють уміннями відновлення, корекції та підтримки рухових функцій спортсменів. Формування вмінь використання здоров'явідновлювальних технологій у професійній діяльності майбутніх фрахівців фрізичної культури і спорту $\epsilon$ складовою частиною прочесу формування фрахових спортивних компетентностей. У своєму дослідженні структурними компонентами готовності майбутніх фахівців фрізичної культури $i$ спорту до використання технологій відновлення здоров'я у професійній діяльності ми виділили аксіологічний, гносеологічний і фізкультурно-оздоровчий компоненти.

Ключові слова: майбутні фахівці фрізичної культури і спорту, технології відновлення здоров'я, професійна підготовка, готовність, компоненти, здоров'явідновлювальні вміння, здоров'явідновлювальні засоби.

Постановка проблеми. У сучасному українському суспільстві основною функцією фізкультурної освіти, що радикально змінює ії якість, виступає функція перетворення освіти на реальний механізм фізичного, морального, психічного та духовного розвитку особистості. Посилення ролі особистості в усіх галузях суспільного прогресу роблять надзвичайно гострими завданнями докорінного перетворення системи фізичного виховання та спорту як головного джерела здорового людського потенціалу суспільства. Для реалізації цих завдань потрібні фахівці фізичної культури і спорту з високою педагогічною та дослідницькою культурою, здатні до професійної творчості в широкому сенсі. Тільки тоді фахівець фізичної культури виправдовує соціальні очікування, коли його особистісна, загальна та професійна культура дозволяють адаптувати проєкт професійної діяльності до конкретних соціальних умов і реалій. 
Формування фахівця нового типу вимагає відмови від групоцентричного типу свідомості, орієнтованого на твердо встановлену систему уявлень, від готових рецептів «на всі випадки життя», руйнування професійних стереотипів, неадекватних соціокультурних умов, що стрімко змінюються, перегляду педагогічного кредо ЗВО, життєвих позицій і цінностей майбутнього фахівця фізичної культури і спорту. Із позицій сьогодення поява нових освітніх креативно-педагогічних парадигм пов'язана зі зміною векторів гармонійного розвитку фахівця фізичної культури і спорту, коли пріоритетним стає розвиток цілісної з фізичної, моральної, соціальної, духовної та психологічної позицій особистості. Нове українське суспільство потребує фахівців фізичної культури і спорту інноваційного типу, що поєднують здатність до творчої співпраці, володіють сучасними інноваційними технологіями відновлення здоров'я, володіють уміннями відновлення, корекції та підтримки рухових функцій спортсменів.

Аналіз актуальних досліджень. У цілому розвиток вищої професійної освіти в галузі фізичної культури і спорту (ФКіС) ґрунтуються на Конституції України, законах України «Про вищу освіту» (2014), Постановах Верховної Ради України «Про забезпечення сталого розвитку сфери фізичної культури і спорту в Україні в умовах децентралізації влади» (2016), Національній стратегії розвитку освіти в Україні на 2012-2021 роки, Цільовій соціальній комплексній програмі розвитку фізичної культури і здоров'я (2016); Наказі Міністерства освіти і науки України «Про затвердження Положення про дистанційне навчання» (2015); інших державних програмах і документах.

Концептуальні, теоретичні й методичні засади професійної підготовки фахівців у галузі ФКіС розкрито в роботах О.Ажиппо, В. Приходько, О. Томенко, В.Бальсевич, Л. Матвєєва, В. Столярова, Ю. Лянного, О. Міхеєнка, П. Рибалка та ін. Методичні аспекти підготовки фахівців фізичної культури і спорту розглядали А. Гладишев, В. Пономарьов, О. Сайкіна та ін. Практичні основи підготовки фахівців ФКіС до створення здоров'язбережувального середовища, використання інноваційних форм рухової активності, формування знань про здоров'я та вмінь його зберігати й відновлювати розкрито в дослідженнях Д.Бермудес, Д. Балашова, Н. Бєлікової, Б. Долинського, М. Носко, В. Приходько та ін.

Значний науковий внесок у розвиток теорії спорту зробили вітчизняні вчені Г.Арзютов, С. Бубка, М. Булатова, М. Дутчак, Г. Лисенчук, І. Максименко, І. Медведєва, В. Платонов, Ю. Шкребтій, Ю. Бріскін, Л. Волков, В. Костюкевич, М. Линець, А. Магльований та ін. Дослідники розкрили у своїх працях провідні напрями оптимізації підготовки спортсменів. 
Водночас аналіз наукових розвідок показує відсутність систематичних теоретичних і практичних досліджень до професійної підготовки майбутніх фахівців фізичної культури і спорту до використання інноваційних технологій відновлення здоров'я спортсменів у професійній діяльності. Ця проблема потребує осмислення їі як цілісної педагогічної системи. Указане доводить актуальність проблематики дослідження й підтверджує необхідність розробки задекларованої проблеми.

Мета статті. Розглянути складові готовності майбутніх фахівців фізичної культури і спорту до використання інноваційних технологій відновлення здоров'я спортсменів у професійній діяльності.

Методи дослідження. Теоретичні методи: системний аналіз наукової, психолого-педагогічної, методичної літератури; узагальнення та систематизація теоретичних відомостей щодо професійної підготовки майбутніх фахівців фізичної культури та спорту й формування їх умінь використання технологій відновлення здоров'я у професійній діяльності.

Виклад основного матеріалу. Сфера діяльності випускників ЗВО фізичної культури та спорту зазнала структурних змін, оскільки відчувається нагальна потреба суспільства в розширенні послуг, що надаються професіоналами у сфері фізичної культури та спорту. У сучасних умовах випускники ЗВО повинні бути підготовлені для роботи в різних ланках системи фізичної культури та спорту. У зв'язку з цим зростає значимість фундаментальної підготовки студентів, їх професійної компетентності у сфері спорту вищих досягнень, під час роботи з різними групами населення (Ажиппо, 2012).

Аналіз проблем кадрового забезпечення у сфері фізичної культури та спорту показує неузгодженість між характером професійної діяльності випускників 3ВО, спрямованістю, організацією та змістом вищої професійної освіти. Сьогодні існує галузь професійної діяльності у спорті, яка включає в себе представлення інтересів організації та спортсменів у різних сферах (як-от укладення договорів, матеріально-технічного забезпечення тренувального процесу, сервісного обслуговування спортсменів, реалізації товарів і послуг клубів, організації реклами й роботи з уболівальниками тощо). Ідеться про працівників професійних команд, агентів, скаутів, які часто $€$ колишніми кваліфікованими спортсменами, знають специфіку того чи іншого виду спорту. Це призводить до необхідності включення цієї галузі в коло інтересів професійного спортивного товариства. Важливою умовою становлення кадрів у сфері «фізична культура і спорт» стає поглиблення й розширення їх компетентностей і у сфері відновлення здоров'я спортсменів. 
Однією 3 характерних рис концепції компетентності фахівця $\epsilon$ підвищення ролі суб'єкта в соціальних перетвореннях і вдосконалення здатності його зрозуміти динаміку процесів розвитку та впливу на їх хід. Ці вимоги професійної компетентності визначаються освітньою політикою держави. Базою, на якій виникає високий професіоналізм і через яку долається функціональна неграмотність фахівця, служить зміст освіти. Зміст освіти кадрів у сфері «фізична культура і спорт» стає варіативним, багатовимірним, поліпарадигмальним з урахуванням підвищення ролі суб'єкта та ступеня сформованості в них професійної компетентності, що включає:

- самоідентифікацію та високу самооцінку особистої професійної компетентності, усвідомлювану як підготовленість і суб'єктивну потенційну готовність (претензійність) до внутрішньопрофесійної поступальної (формальної та неформальної) і міжпрофесійної мобільності;

- позитивне ставлення до професійної діяльності в цілому й до об'єктів (суб'єктів) діяльності;

- здатність до рефлексії, самоконтролю та корекції процесу й результату професійної діяльності;

- готовність до критичної самооцінки, постійного підвищення кваліфікації; позитивну мотивацію до прояву компетентності;

- ціннісно-смислові уявлення (відносини) до змісту й результату професійної діяльності;

- націленість і готовність до суспільно схвалюваної продуктивної професійної діяльності;

- готовність і прагнення пізнавати й удосконалювати самого себе (Жигірь, 2014).

Отже, формування загальних професійних компетентностей у майбутніх фахівців ФКіС - це комплексний, інноваційний (нововведення), педагогічний процес професійної підготовки майбутніх фахівців ФКіС на основі єдності та взаємозв'язку тренувальної та навчальної діяльності, що включає формування у студентів «здорового способу життя»; оздоровчорекреаційних, загально-прикладних та спортивних компетентностей, що сприяють накопиченню інтелектуального та психофізичного потенціалу для майбутньої професійної діяльності (Шеремет, 2011).

Формування вмінь використання здоров'явідновлювальних технологій у професійній діяльності майбутніх фахівців ФКіС є складовою частиною процесу формування фахових спортивних компетентностей (Ажиппо, 2012; Воронін, 2006). 
Інтенсифікація процесу фізичного виховання та спортивного тренування без шкоди для здоров'я спортсменів можлива лише за раціональної побудови занять і використання системи відновлювальних заходів медико-біологічних, психологічних і активного відпочинку $з$ виконанням фізичних вправ невисокої інтенсивності. Загальні закономірності відновлення функцій організму після напруженої роботи полягають у такому:

1) швидкість і тривалість відновлення більшості функціональних показників знаходяться в прямій залежності від потужності (інтенсивності) роботи. Це означає, що чим коротше виконана робота, тим менше період відновлення;

2) відновлення різних функцій відбувається з різною швидкістю, так що досягнення ними вихідного рівня відбувається гетерохронно;

3) повнота та швидкість відновлення організму залежать від тренувальних ефектів, викликаних різними за обсягом навантаженнями. Близький тренувальний ефект - це викликані тренувальним заняттям зрушення в стані організму до моменту завершення або в межах його окремих частин. Якщо навантаження на занятті було досить високим, то воно пов'язане зі зниженням працездатності й функціонального стану окремих систем організму. Слідовий тренувальний ефект - це те, на що перетвориться, трансформується найближчий ефект залежно від часу, що проходить до наступного заняття;

4) за загальними ознаками відновлення він може бути троякого роду: пов'язане з недовідновленням, з повним відновленням і вираженим надвідновленням (суперкомпенсацією).

Вивчення зрушень функціонального стану організму спортсмена та його працездатності у процесі взаємодії цих двох ефектів $є$ важливим завданням спортивної науки, від вирішення якої залежить успіх усієї підготовки в цілому (Добротина, 1999).

У практиці фізичного виховання й особливо професійного спортивного тренування використовується широкий комплекс різноманітних вправ різної тривалості й інтенсивності, що вимагає відновлювальних заходів, для проведення яких необхідні добре оснащені спортивно-оздоровчі центри, які мають складну й дорогу медичну апаратуру. Тому наукові дослідження, виконані в останні 15-20 років, присвячені переважно комплексному дослідженню відновлювальних заходів після інтенсивного тренувального навантаження в умовах стаціонарних відновлювальних центрів. Однак, у процесі тренувальних занять і змагань на стадіонах і в спортивних залах проведення повного комплексу відновних заходів неможливо. Тому тренери, 
масажисти й самі спортсмени використовують найбільш поширені у практиці фізичні засоби відновлення. До них належать прийоми спортивного масажу й фізичні вправи невисокої інтенсивності, спрямовані на розтягування м'язових груп, які брали активну участь у виконаній роботі (стретчинг) i на їх розслаблення. Ці вправи активують кровообіг у м'язах, усувають накопичену молочну кислоту й інші продукти метаболізму, відновлюють частоту серцевих скорочень, енергетичні запаси організму (АТФ, креатинфосфату, глікоген), а також виконують функції активного відпочинку, тим самим прискорюючи відновлення.

Медико-біологічні засоби відновлення, що сприяють підвищенню працездатності організму, а також перешкоджають виникненню різних негативних наслідків від виробничої та фізкультурно-спортивної роботи, займають особливе місце серед інших засобів відновлення. До їх числа належать харчування, білкові препарати та спортивні напої, фармакологічні засоби, лікарські рослини, оксигенотерапія, гідропроцедуи, застосування мазей, гелів, кремів, фізіотерапії, масажу, застосування тейпів (фіксуючих пов'язок), фізичні вправи та ін.

Отже, професійна підготовка майбутніх фахівців фізичної культури і спорту до використання інноваційних технологій відновлення здоров'я спортсменів у професійній діяльності передбачає формування відповідної готовності майбутніх фрахівців фізичної культури і спорту, яка $\epsilon$ інтегрованою характеристикою особистісних якостей майбутніх фахівців фрізичної культури і спорту. У своєму дослідженні структурними компонентами готовності майбутніх фахівців фізичної культури і спорту до використання технологій відновлення здоров'я у професійній діяльності ми виділили аксіологічний, гносеологічний і фрізкультурно-оздоровчий (рис. 1).

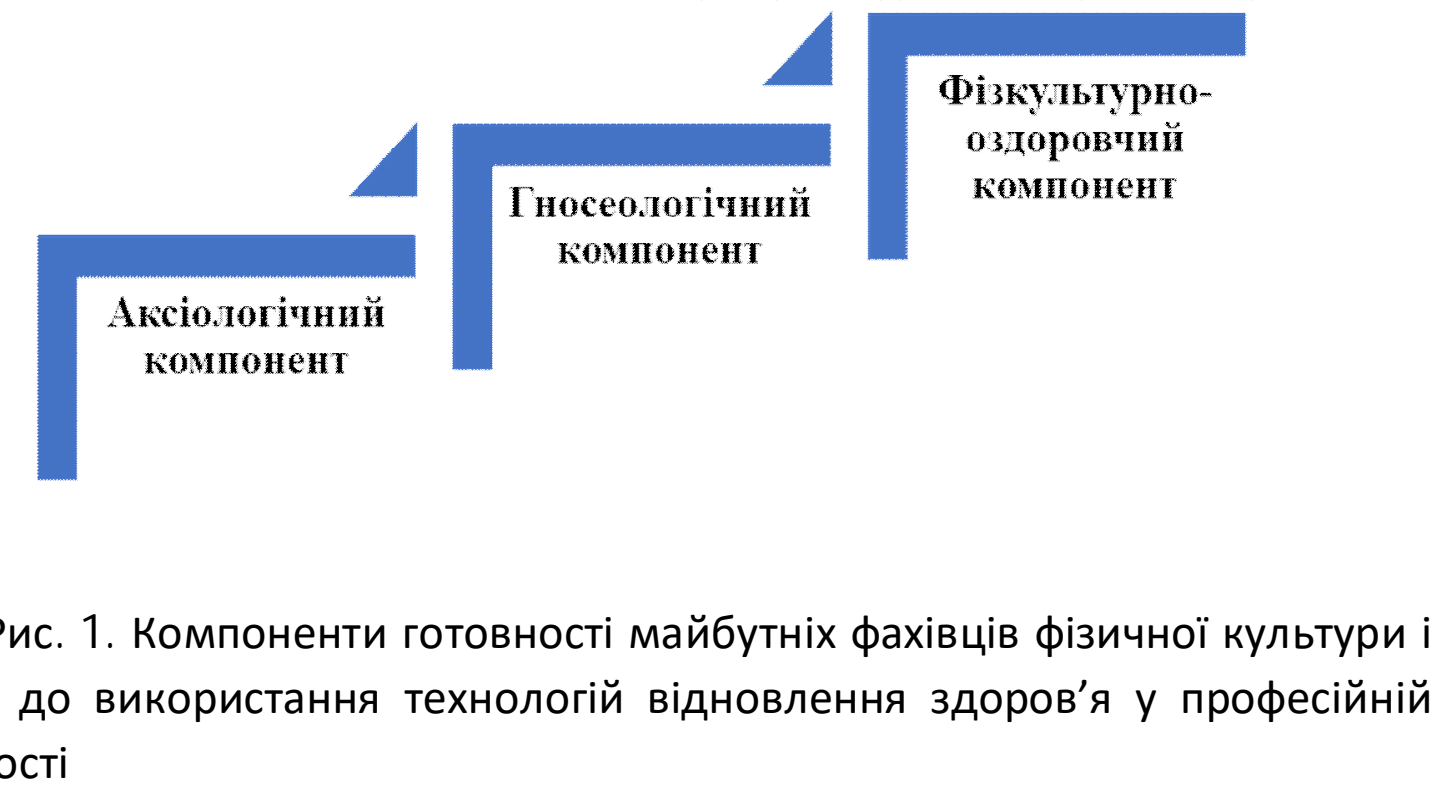


Аксіологічний компонент готовності майбутніх фахівців фізичної культури і спорту до використання технологій відновлення здоров'я у професійній діяльності передбачає, що істотним показником розвитку особистості фахівця фізичної культури і спорту є самооцінка його власної діяльності, яка формується під впливом оцінок керівника або тренеравикладача, а також товаришів по роботі, студентів навчальної групи. Тривалий неуспіх, підкріплений систематичними негативними оцінками оточуючих, негативно позначається на самооцінці. Разом із тим об'єктивна оцінка результатів, своєчасна підтримка керівником або тренеромвикладачем допомагають спортсмену, який знаходиться на межі зриву, відновити позитивну оцінку. Не менш важливим $є$ позитивне мислення. Цей спосіб оздоровлення організму тісно пов'язаний із таким психологічним феноменом, як віра. На відміну від ірраціональної релігійної віри психологічна віра пов'язана з продуктивним мисленням і здатністю людини діяти відповідно до виробленої установки. Позитивне мислення визначається з вірою людини у свої сили, високою самооцінкою та оптимістичним поглядом на житя, який виробляється у процесі виховання, але більшою мірою - у процесі самовиховання (Соколенко, 2008).

Для відновлення сил і працездатності часто виникає необхідність активізувати протікання відновних процесів, посилити мобілізацію резервів, створюючи тим самим передумови для формування іншого типу станів організму - станів стійкої високої працездатності. Психологічні засоби реабілітації в останні роки набули широкого поширення особливо у фізкультурно-спортивній практиці. За допомогою психологічних впливів можна знизити рівень нервово-психічної напруги, швидше відновити витрачену нервову енергію та тим самим зробити істотний вплив на прискорення процесів відновлення в різних системах організму. Однією з умов успішної реалізації психотерапії, психопрофілактики та психогігієни $\epsilon$ об'єктивна оцінка результатів психологічних впливів.

Гносеологічний компонент готовності майбутніх фахівців фізичної культури і спорту до використання технологій відновлення здоров'я у професійній діяльності передбачає формування спеціальних знань у студентів у таких напрямах:

1) раціональне планування фізкультурно-оздоровчого процесу: науково-обґрунтоване перспективне планування фізкультурно-оздоровчої діяльності, оптимальна побудова тренувальних мікро, мезо- і макроциклов, різноманітність засобів і методів фізичного виховання, відповідність тренувального навантаження рівнях функціональної та 
фізичної підготовленості, дотримання дидактичних принципів під час планування тренувального процесу, лікарсько-педагогічні спостереження;

2) оптимальна побудова тренувального занятя: відповідність тренувального заняття даного циклу тренування, проведення в підготовчій частині загальної та спеціальної розминки, наявність спеціальних фізичних вправ в основній частині заняття, обов'язкове проведення заключної частини тренувального заняття, відповідність навантаження індивідуальним можливостям, широке використання релаксаційних, дихальних вправ на розслаблення, регулярність занять, раціональне чергування навантаження й відпочинку, їх послідовність, свідомість, зацікавленість, об'єктивна оцінка результатів, педагогічний та лікарський контроль і самоконтроль;

3) ведення здорового способу життя: культура навчальних праці й побуту, культура міжособистісного спілкування й поведінки, самоврядування й самоорганізація, організація оптимальних режимів харчування, сну, перебування на повітрі, рухової активності, дотримання санітарно-гігієнічних вимог, загартовування, відмова від шкідливих звичок, оптимальне поєднання праці й відпочинку.

Фізкультурно-оздоровчий компонент готовності майбутніх фахівців фізичної культури і спорту до використання технологій відновлення здоров'я у професійній діяльності передбачає формування спеціальних умінь і навичок, які включають у себе: раціональне планування тренувального процесу відповідно до функціональних можливостей організму спортсмена, правильне поєднання загальних і спеціальних засобів, оптимальну побудову тренувальних і змагальних мікро- i макроциклів, широке використання перемикань, чітку організацію роботи й відпочинку; правильну побудову окремого тренувального занятя 3 використанням засобів зняття втоми; спрямоване варіювання інтервалів відпочинку між окремими вправами та тренувальними заняттями; розробку системи планування з використанням різних відновлювальних засобів у місячних і річних циклах підготовки; розробку спеціальних фізичних вправ із метою прискорення відновлення працездатності.

Висновки та перспективи подальших наукових розвідок. У сучасних умовах реформування освітньої системи України однією з нагальних проблем $\epsilon$ підготовка висококваліфікованого фахівця, зокрема сектора фізичної культури і спорту. Випускники університетів фізичної культури і спорту повинні бути готові до професійної діяльності у специфічних умовах, серед яких енергійний характер рухових дій і особливі умови діяльності, що вимагає від них високого рівня сформованості таких якостей, як активність, здатність 
до адаптації в соціальній і професійній сферах, високий рівень фізіологічних і психологічних можливостей. Здатність фахівців такого профілю виконувати професійну діяльність залежить не тільки від їх професійної підготовки, але й вимагає високого рівня фізичного, психічного, соціального й духовного здоров'я. Разом із тим, в останні роки в результаті забруднення навколишнього середовища й соціально-економічних перетворень, які призвели до зниження рівня життя, погіршився стан здоров'я населення України. Тому для випускників університетів фізичної культури і спорту найважливішим завданням $€$ формування вмінь використання технологій відновлення здоров'я у професійній діяльності як складової їх професійної компетентності. У своєму дослідженні структурними компонентами готовності майбутніх фахівців фізичної культури і спорту до використання технологій відновлення здоров'я у професійній діяльності ми виділили аксіологічний, гносеологічний і фізкультурно-оздоровчий.

Разом із цим постає питання оцінки рівня сформованості готовності використання технологій відновлення здоров'я у професійній діяльності та розробки відповідних критеріїв. У загальному вигляді це дозволяє обґрунтувати комплекс педагогічних умов, що забезпечують оптимальне функціонування даного процесу, дає можливість визначити вихідні позиції, стан сформованості вмінь використання технологій відновлення здоров'я майбутніх фахівців фізичної культури і спорту, розробити методику їх формування в майбутніх фахівців.

\section{ЛITEPATУРА}

Ажиппо, О. Ю. (2012). Підготовка майбутніх учителів фрізичної культури до професійної діяльності в загальноосвітніх навчальних закладах (теоретичний і методичний аспекти). Харків: Цифрова друкарня № 1. (Agippo, О. Yu. (2012). Preparation of future physical education teachers for professional activity in secondary schools (theoretical and methodological aspects). Kharkiv: Digital Printing House № 1.)

Воронін, Д. Є. (2006). Формування здоров'язберігаючої компетентності студентів вищих навчальних закладів засобами фізичного виховання (автореф. дис. ... канд. пед. наук: 13.00.07). Херсон. (Voronin, D. E. (2006). Formation of healthpreserving competence of students of higher educational institutions by means of physical education (PhD thesis abstract)). Kherson.

Добротина, Н. А. (1999). Биология человека, экология и здоровье (антропологическая валеология). Н. Новгород. (Dobrotina, N. A. (1999). Human biology, ecology and health (anthropological valeology). N. Novgorod).

Жигірь, В. І. (2014). Оцінювання професійної компетентності фахівця як фактор його формування. Наукові записки Бердянського державного педагогічного університету. Сер.: Педагогічні науки, 2, 40-47. (Zhigir, V. I. (2014). Assessment of the professional competence of the specialist as the factor of its formulation. Scientific Notes of the Berdyansk State Pedagogical University. Ser.: Pedagogical Sciences, 2, 40-47.).

Соколенко, О. І. (2008). Формування ціннісного ставлення студентів вищих педагогічних навчальних закладів до свого здоров'я (автореф. дис. ... канд. пед. 
наук : 13.00.04). Луганськ. (Sokolenko, O. I. (2008). Formation of the value attitude of students of higher pedagogical educational institutions to their health (PhD thesis abstract). Lugansk).

Шеремет, І. В. (2011). Професійно-прикладна фізична підготовка як один із шляхів формування компетентності фахівця. Вісник Запорізького національного універсumemy, 1 (5), 73-81. (Sheremet, I. V. (2011). Professional and applied physical training as one of the ways to form the competence of a specialist. Bulletin of Zaporizhia National University, 1 (5), 73-81).

\section{PEЗЮME}

Твердохлебова Юлия, Красилов Андрей, Лянной Михаил. Компоненты готовности будущих специалистов физической культуры и спорта к использованию технологии восстановления здоровья в профессиональной деятельности.

Новое украинское общество нуждается в специалистах физической культуры и спорта инновационного типа, сочетающих способность $к$ творческому сотрудничеству, которые владеют современными инновационными технологиями восстановления здоровья, обладают умениями восстановления, коррекции и поддержки двигательных функций спортсменов. Формирование умений использования здоровьевосстанавливающих технологий в профессиональной деятельности будущих специалистов физической культуры и спорта является составной частью прочесса формирования профессиональных спортивных компетентностей. В своем исследовании структурными компонентами готовности будущих специалистов физической культуры и спорта к использованию технологий восстановления здоровья в профессиональной деятельности мы выделили аксиологический, гносеологический и физкультурно-оздоровительный компоненты.

Ключевые слова: будущие спечиалисты физической культуры и спорта, технологии восстановления здоровья, профессиональная подготовка, готовность, компоненты, здоровьевосстанавливающие умения, здоровьевосстанавливающие средства.

\section{SUMMARY}

Tverdokhliebova Julia, Krasilov Andrii, Liannoi Mykhailo. Components of future physical culture and sports specialists' readiness to use technologies of health restoration in the professional activity.

The new Ukrainian society needs specialists in physical culture and sports of an innovative type, combining the ability for creative cooperation, who possess modern innovative technologies for health restoration, have the skills to restore, correct and support the motor functions of athletes. The formation of the skills of using health-restoring technologies in the professional activity of future specialists in physical culture and sports is an integral part of the process of professional sports competences formation. In our study, we have identified the axiological, epistemological and physical culture and health-improving components as the structural components of the readiness of future physical culture and sports specialists to use health restoration technologies in professional activity.

The axiological component of readiness of future physical culture and sports specialists to use technologies of restoration of health in professional activity assumes that the essential indicator of development of the personality of the specialist of physical culture and sports is self-assessment of his own activity which is formed under the influence of estimations of the head or trainer, co-workers, peer students. The epistemological component of readiness of future specialists of physical culture and sports to use technologies of restoration of health in professional activity provides formation of special knowledge at students in the following directions, rational planning of physical culture and 
health process: optimal construction of the training session, leading a healthy lifestyle. Physical training and health component of the readiness of future specialists in physical culture and sports to use health technologies in professional activities involves formation of special skills, which include: rational planning of the training process in accordance with the functional capabilities of the athlete, the right combination of general and special tools, optimal construction of training and competitive micro- and macrocycles, extensive use of switches, clear organization of work and rest; correct construction of a separate training session with the use of fatigue relievers; directed variation of rest intervals between individual exercises and training sessions; development of a planning system using various recovery tools in monthly and annual training cycles; development of special physical exercises in order to accelerate recovery.

Key words future specialists in physical culture and sports, health restoration technologies, professional training, readiness, components, health-restoring skills, healthrestoring means.

\title{
удк 378:37.011.3
}

\author{
Аліна Трофименко \\ Сумський державний педагогічний \\ університет імені А. С. Макаренка \\ ORCID ID 0000-0002-9281-6706
}

DOI 10.24139/2312-5993/2020.10/269-279

\section{ФАСИЛІТАЦІЙНА КОМПЕТЕНТНІСТЬ ЯК НЕВІД'ЄМНА СКЛАДОВА ПРОФЕСІЙНОЇ КОМПЕТЕНТНОСТІ СУЧАСНОГО ВЧИТЕЛЯ}

У статті проаналізовано підходи до визначення змісту поняття «фрасилітаційна компетентність» у контексті невід'ємної складової профресійної компетентності сучасного вчителя. Визначено особливості застосування ії провідних механізмів та принципів у професійній діяльності педагога. Наголошено на фасилітуючій позиції вчителя, яка полягає в саморозвиткові учнів на основі врахування власних схильностей $i$ прагнень. Зазначено перспективи подальших наукових досліджень у даному напрямі, а саме обгрунтування наукових підходів до формування фасилітаційної компетентності в майбутніх учителів природничих дисциплін.

Ключові слова: фасилітація, педагогічна фасилітація, компетентність, профресійна компетентність, фрасилітаційна взаємодія, фрасилітатор, фасилітуюча позиція, екофасилітація, фасилітаційна компетентність.

Постановка проблеми. Бути сучасним учителем у наш час - це означає бути готовим до змін і нововведень. I це дійсно так, адже на сьогоднішній день в умовах реформування педагогічної науки та освіти до вчителя висуваються все нові й нові вимоги. Насамперед, це повинна бути умотивована, творча та віддана даній професії людина, на плечі якої покладена не лише «передача знань», а в першу чергу - виокремлення найважливішого та найбільш цінного з величезної кількості інформації. Саме тому від учителя залежить, яким способом «сіяти добре, мудре, вічне», щоб значно полегшити сприйняття й розуміння учнями сучасного світу. 